Available online at website : http://e-journal.adpgmiindonesia.com/index.php/jmie JMIE: Journal of Madrasah Ibtidaiyah Education, 3(2), 2019, 168-178

\title{
PENGEMBANGAN LEMBAR KERJA PESERTA DIDIK (LKPD) MATEMATIS BERBASIS PBL TERINTEGRASI NILAI-NILAI ISLAM DI SEKOLAH DASAR ISLAM TERPADU
}

Zubaidah Amir MZ1), Fitria Anggraini'), Kusnadi'3), Alfiah' ${ }^{4}$

Universitas Islam Negeri Sultan Syarif Kasim, Riau

Email: zubaidah.amir@uin-suska.ac.id ${ }^{1)}$, fitriaanggraini8877@gmail.com²), kusnadi@uin-suska.ac.id ${ }^{3}$, alfiah@uin-suska.ac.id4)

Naskah diterima : 20 Agustus 2019, direvisi : 18 September 2019, disetujui : 25 September 2019

\begin{abstract}
This research is development research using a 4-D model, but in this study, researchers modified it to 3-D (Define, Design, Development). This study aims to produce a PBL-based Student Worksheet (SW) Integrated Islamic Values that are valid, practical, and effective. This research was conducted at SDIT Raudhaturrahmah sub-district Marpoyan Damai, Pekanbaru, Riau. The subject of this study were material experts and media from lecturers and teachers, as well as Raudhaturrahmah Pekanbaru students. The sample in this study was class V Al-Halim as the experimental class and class V Al-Fattah as the control class. The object of this research is the PBL Mathematical Integrated Islamic Values. The instruments of data collection were questionnaires, and posttests. The data analysis technique used is quantitative descriptive analysis and qualitative descriptive analysis. Based on the validity test, the SW based on PBLBased Islamic Values was stated as a very valid category with a percentage of validity level of $87.61 \%$, and very practical with a percentage of the practicality of $84.39 \%$. And effective, because based on the results of t-test analysis, there are differences in learning outcomes between experiments using problem-based SW mathematics integrated Islamic values with the control class that does not use problem-based SW integrated Islamic values. Besides, the percentage of student learning completeness reaches $85 \%$.
\end{abstract}

Keywords: Pengembangan, LKPD, PBL, Nilai-nilai Islam

Pengutipan: . Zubaidah Amir, dkk. (2019). Pengembangan Lembar Kerja Peserta Didik (LKPD) Matematis Berbasis PBL Terintegrasi Nilai-Nilai Islam di SDIT Raudhaturrabmah Pekanbaru. JMIE: Journal of Madrasah Ibtidaiyah Education,3(2), 2019, 168-178. jmie.v3i2.132.

Permalink/DOI: http://dx.doi.org/10.32934/jmie.v3i2.132 


\section{INTRODUCTION}

Matematika merupakan mata pelajaran wajib dalam setiap jenjang pendidikan, mulai dari tingkat sekolah dasar sampai pergururan tinggi. Matematika merupakan salah satu mata pelajaran yang diujikan dalam Ujian Nasional (UN). Sebagai mata pelajaran yang wajib, tentu harus memiliki kelengkapan bahan ajar untuk mendukung tercapainya kompetensi sesuai dengan apa yang diharapkan. Kelengkapan bahan ajar tersebut antara lain; buku ajar, Lembar Kerja Peserrta Didik (LKPD), sarana, dan prasana yang mendukung. Tapi justru bahan ajarnya inilah yang jadi masalah di lapangan, baik dari segi kualitasnya maupun secara kuantitas.

Bahan ajar yang ada sekarang ini baik buku, ataupun Lembar Kerja Peserta Didik (LKPD) yang disarankan pemerintah baik secara elektronik maupun tidak, sedikit banyaknya perlu disempurnakan dan disesuaikan dengan kondisi daerah ataupun sekolah yang menggunakannya. Hal ini juga senada dengan Norsanty dan Chairani (2016) bahwa pengembangan LKS yang disesuaikan dengan kondisi dan kebutuhan peserta didik dianggap perlu dilakukan. Seperti sekolah Islam, alangkah baiknya sekolah Islam memiliki bahan ajar seperti LKPD yang dapat mencirikan identitas keislamannya demi mendukung terciptanya siswa yang berkarakter.

LKPD memiliki banyak pengertian dari para ahli pendidikan. Menurut Depdiknas (Rofiah, 2014) menyatakan bahwa LKPD adalah lembaran-lembaran berisi petunjuk, langkah-langkah untuk menyelesaikan suatu tugas yang harus dikerjakan oleh peserta didik. LKPD harus memiliki unsur-unsur yang tepat serta langkah-langkah yang benar dalam penyusunannya agar sesuai dengan tujuan pembelajaran yang ingin dicapai. Seperti yang disampaikan Kementerian Pendidikan Nasional dalam menyatakan bahwa LKPD harus memiliki delapan unsur meliputi, (1) judul, (2) petunjuk belajar, (3) kompetensi dasar atau materi pokok, (4) waktu penyelesaian, (5) peralatan dan bahan, (6) informasi singkat tentang langkah kerja, (7) tugas yang harus dilaksanakan, dan (8) Penilaian (Partasiwi dkk, 2017).

Berdasarkan hasil wawancara dan pengamatan di SDIT Raudhaturrahmah Pekanbaru, guru tidak sempat untuk membuat LKPD sendiri, mereka hanya menggunakan LKPD yang sudah tersedia. LKPD yang selama ini digunakan bukanlah hasil rancangan guru melainkan LKPD yang dibeli dari penerbit.Seperti diketahui LKPD dari penerbit tentu masih bersifat umum yang belum tentu sesuai dengan kondisi siswanya, kondisi sekolah yang notabenenya Islam, kondisi kelas, dan materi pelajaran, padahal yang lebih tahu siswanya adalah gurunya. Guru berusaha mengikuti apa yang ada dalam buku baik contoh soal ataupun latihan yang diberikan. LKPD yang ada kebanyakan berupa latihan soal-soal.

Banyak kekurangan yang terdapat pada LKPD yang selama ini digunakan antara lain, dari aspek media tampilannya belum menarik, tidak berwarna, tidak ada gambar-gambar, dan tidak ada petunjuk kerja. Dari aspek materi, LKPD ini hanya memuat ringkasan materi, contoh soal dan latihan yang tidak berorientasi pada penyelesaian masalah kebanyakan 
berupa operasi hitung dan sedikit soal pemecahan masalah namun masalah yang disajikan berupa simbol belum dan belum menggambarkan kehidupan sehari-hari. Sehingga dibutuhkan inovasi dalam rangka melengkapi kekurangan LKPD yang ada.

Selain itu LKPD yang ada belum terintegrasi nilai-nilai Islam baik nilai syariat islam seperti, nilai khlak, dan nilai tauhid. Pada zaman sekarang ini, Integrasi nilai-nilai islam sudah mulai dikembangkan mulai dari tingkat sekolah dasar sampai perguruan tinggi. Inilah yang membedakan sekolah umum dengan sekolah Islam. Matematika yang diintegrasikan dengan nilai-nilai- Islam tidak harus menghilangkan keunikan keilmuannya. Keduanya tetap berjalan sesuai standarnya dan terbungkus dalam satu kemasan yaitu LKPD teintegrasi nilai-nilai Islam. sehingga tidak ada lagi pemahaman bahwa ilmu umum kurang penting dibanding ilmu agama, maupun sebaliknya (Mauluah, L. 2014). Selain itu, hal ini agar tidak ada lagi anggapan yang menyatakan dikotomi keilmuan bahwa matematika tidak ada hubungannya dengan ilmu agama (MZ, 2013). Dengan demikian perlu dikembangakn LKPD berbasis keislaman.

Dalam pembelajaran, dibutuhkan suatu model sebagai cara penyampaian pesan pembelajaran. Model pembelajaran berbasis masalah adalah suatu lingkungan belajar dimana masalah mengendalikan proses belajar Sumatri (2015). Pembelajaran yang berorientasi pada masalah, akan melatih siswa cakap dalam menyelesaikan masalah, tidak saja mengasah kognitif siswa tapi juga melatih keterampilan siswa dalam pemecahan masalah. Hal tersebut sejalan dengan perspektif Islam yang dikemukaan oleh Nata (2011: 252) bahwa pemecahan masalah adalah merupakan bagian dari agenda kehidupan, bahkan kehidupan itu sendiri sebenarnya adalah sebuah masalah. Oleh karena itu dalam LKPD dapat diaplikasikan langkah-langkah pemecahan masalah sebagaimana yang dirumuskan dalam Problem Based Learning (PBL).

Langkah-langkah Pembelajaran PBL adalah: Orientasi siswa pada masalah; mengorganisir siswa untuk belajar; membimbing investigasi individual maupun kelompok; mengembangkan dan menyajikan hasil karya; menganalisis dan mengevaluasi proses penyelesaian masalah (Wulandari, E. 2012, dan Lintang dk, 2017). Semua tahapan ini tercakup dalam proses pembelajaran, baik dalam bahan ajar (LKPD) maupun pada skenario pembelajaran.

Model Pembelajaran Problem Based Learning ini memiliki beberapa keunggulan, diantaranya:1) dapat membuat pendidikan di sekolah menjadi relevan dengan kehidupan, 2) dapat membiasakan para siswa menghadapi dan memecahkan masalah secara terampil dalam kehidupan bermasyarakata, 3) dapat meransang pengembangan kemampuan berfikir secara kreatif dan menyeluruh (Wulandari, E. 2012). Sedangkan kelemahan dari PBL diantaranya: 1) sering tejadi kesulitan dalam menemukan permasalah yang sesuai dengan tingkat berfikir siswa. 2) memerlukan waktu lama, 3) sering mengalami kesulitan dalam perubahan kebiasaan belajar (Nur dkk, 2016). Namun demikian Stepien \& Gallager, dalam Setiawan dkk (2012: 
120) mengemukakan bahwa pembelajaran problem based learning telah dibuktikan lebih efektif dari pada pengajaran konvensional dalam memberikan kesempatan untuk mentransfer pengetahuan dan keterampilan dari kelas ke tempat kerja. Hasil riset senada juga demikian, hasil penelitan Wulandari (2012), bahwa PBL dapat meningkatkan kemampuan IPA siswa kelas V SD di Kebumen.

Berdasarkan kenyataan yang ada maka peneliti akan mengembangkan LKPD yang berorientasi pada masalah dalam perspektif Islam. Dalam pengerjakannya, langkah awal kegiatan belajar siswa disajikan masalah, kemudian siswa mengorganisir masalah untuk didiskusikan masalah dasar apa yang ditanyakan pada masalah tersebut. Agar siswa dapat menjawabnya maka siswa mengumpulkan informasi baik dari berbagai sumber, setelah itu siswa mempresentasikan hasil diskusi dan refleksi dan evaluasi. Reflelsi untuk melihat sejauh mana keterhubungan siswa akan nilai-nilai Islam dari masalah perspektif Islam yang disajikan. Sedangkan evaluasi di gunakan untuk mengukur sejauh mana kepahaman siswa terhadap materi pelejaran yang ada pada LKPD.

Nilai-nilai Islam yang dimasukan dalam LKPD ini adalah nilai akhlak, syariat, dan tauhid namun lebih prioritas pada nilai akhlak. Hal ini merujuk pada (Rofiah, 2016) bahwa pendidikan islam diantaranya mencakup iman, aqidah, tauhid, akhlak dan sebagainya. Nilai akhlak dan syariat, diintegrasikan pada soal-soal pada LKPD yang dikembangkan disajikan dalam bentuk alur cerita. Proses Integrasi dapat dilakukan dengan berbagai cara seperti melalui pemberian simbol, alat/ media keislaman, dan cerita, soal dan lainnya (MZ, 2013), (Salafudin. (2015). Dalam penelitian ini nilai keislaman tauhid, disajikan memalui cerita inspiratif yang bertemakan rahasia sedekah.

Integrasi nilai-nilai Islam ini disajikan melalui strategi pembelajaran matematika terintegrasi nilai-nilai Islam. Secara rinci Yasri dalam Hariyani (2013: 153) mengemukakan penjelasan strategi pembelajaran yang dikaitkan dengan penanaman nilai-nilai ajaran Islam, antara lain: menyebut nama allah, penggunaan istilah atau nama-nama Islam, ilustrasi visual islami, aplikasi / contoh-contoh, menysipkan ayat atau hadits yang relevan, jaringan topik, ayat-ayat kauniyah dan penelusuran sejarah.

Agar lebih spesifik lagi maka LKPD ini difokuskan pada soal-soal penalaran berbasis PBL dalam perspektif Islam. Adapun indikator kemampuan penalaran yang dikaji dalam penelitian ini mengadopsi NCTM dalam Hendriana (2018) yaitu: 1) Mengenal penalaran dan pembuktian sebagai aspek dasar; 2) Membuat dan menyelidiki konjektur (dugaan, hipotesis) matematika; 3) Mengembangkan dan mengevaluasi argumen dan bukti secara matematis, 4) Memilih dan mengembangkan berbagai jenis penalaran dan metode pembuktian.

Menurut Ruseffen dalam Mikrayanti (2016:102) matematika terbentuk sebagai hasil pemikiran manusia yang berhubungan dengan ide, proses dan penalaran. Depdiknas dalam mikrayanti menyatakan bahwa materi matematika dan penalaran matematis dua hal yang 
sangat terkait dan tidak dapat dipisahkan, karena materi matematika dipahami melalui penalaran dan penalaran dipahami dan dilatihkan melalui belajar matematika.

Islam sebagai agama memiliki kepedulian yang tinggi dalam memecahkan berbagai masalah yang dihadapi umat manusia dan sangat memberi perhatian akan pentingnya kemampuan memecahkan masalah bagi umat manusia. Islam memandang bahwa memecahkan masalah bukan hanya sebagai jalan untuk menempa diri agar memiliki ketahanan fisik dan mental serta mendapatkan hikmah dan pendidikan lainnya, sebagai bagian dari agenda kehidupan yang harus dijalani.

Berdasarkan latar belakang yang sudah dipaparkan di atas maka peneliti mengadakan penelitian yang berjudul "Pengembangan LKPD Matematika Berbasis Problem Based Learning (PBL) Terintegrasi Nilai-Nilai Islam di SDIT Raudhtaurrahmah Pekanbaru. LKPD yang dikembangkan haruslah valid, praktis serta efektif terhadap peningkatan kemampuan siswa sebagai mana dinyatakan oleh (Nieeven dalam sannah dkk (2015: 184-196)). Dalam penelitian ini dirumuskan permasalahan yaitu Bagaimana Produk Hasil Pengembangan LKPD matematis berbasis Problem Based Learning (PBL) terintegrasi nilai-nilai Islam pada pokok bahasan volume kubus dan balok dapat memfasilitasi kemampuan penalaran siswa kelas V SDIT Raudhaturrahmah Pekanbaru, jika dilihat dari kevalidan, kepraktisan dan keefektifannya? kekefektifan dalam penelitian ini dilihat dari aspek kemampuan penalaran matematis siswa.

\section{METODE PENELITIAN}

Penelitian ini adalah Research and Development (R\&D). Model pengembangannya menggunakan desain pengembangan 4-D yang dikembangkan oleh Thiagarajan (Syahrir dan Susilawati, 2015). Namun karena keterbatasan waktu dan biaya maka model ini dimodifikasi dimofikasi menjadi 3-D yaitu Define, Desain dan Develop. Produk yang dikembangkan adalah LKPD matematika pada volume kubus dan balok untuk memfasilitasi kemampuan penalaran matematis siswa.

Subjek penelitian ini adalah para ahli materi dan media yang berasal dari dosen dan guru, serta siswa Raudhaturrahmah Pekanbaru. Sampel dalam penelitian ini adalah kelas siswa kelas V Al-Halim sebagai kelas eksperimen serta siswa kelas V Al-Fattah sebagai kelas kontrol. Objek penelitian ini adalah LKPD Matematis berbasis PBL Terintegrasi Nilai-nilai Islam. Data validitas dikumpulkan melalui lembar validasi, data kepraktisan melalui angket siswa, data efektifitas dikumpulkan melalui tes penalaran matematis. Teknik analisis data yang digunakan untuk menganalisis data yang diperoleh dalam penelitian ini adalah analisis statistik deskriptif dan uji t untuk data efektifitas untuk meelihat perbandingan hasil uji coba kelas eksperimen dengan kelas kontrol. selain itu efektifitas juga dilihat dari nilai KKM siswa 
(Prasetyo dalam Sannah dkk (2015: 184-196) dengan syarat siswa yang tuntas jumlahnya lebih besar atau sama dengan 85\%. Data Valididtas dan kepraktisan dibagi dalam beberapa kategori (Sangat Valid/praktis, Valid/Praktis, Cukup valid/praktis, kurang valid/praktis) (dimodifikasi dari Aviyanti, 2015).

\section{HASIL DAN PEMBAHASAN}

Hasil penelitian dibagi menjadi dua, yaitu hasil pengembangan LKPD dan hasil uji coba pengembangan LKPD matematika berbasis Problem Based Learning (PBL) spesifikasi untuk memfasilitasi kemampuan penalaransiswa materi bangun kubus dan balok pada model pengembangan sistem instruksional Thiagarajan, (dikenal dengan model 4-D) yang dimodifikasi tidak sampai pada tahap penyebaran (disseminate).

Langkah pertama pengembangan LKPD ini adalah tahap define (Buchori dkk, 2014) yang terdiri dari analisis awal adalah 1) tahap awal yang dilakukan dalam penelitian pengembangan untuk menentukan masalah dasar yang diperlukan dalam mengembangan sehingga diperlukan pengembangan bahan ajar; 2) Analisis siswa, 3) Analisis konsep, 4) Analisis tugas, 5) spesifikasi tujuan pembelajaran. Berdasarkan analisis konsep dan tugas, maka dapat dirumuskan tujuan pembelajaran untuk materi pokok bahasan volume kubus dan balok kelas V SD.

Kedua adalah tahap Perencanaan (Design) Tahap ini untuk merancang LKPD Pada tahap perencanaan ini peneliti juga merancang instrumen penelitian untuk menguji terlaksananya uji coba terbatas. Tahap perencanaan ini terdiri dari empat langkah yaitu penyusunan tes kemampuan penalaran, pemilihan media, pemilihan format, dan penulisan LKPD.

Ketiga adalah tahap Develop (pengembangan). Tahap ini adalah tahap untuk menghasil protoype III (draf III). Draf III revisi draf I dan draf II. Saran oleh ahli materi dan media serta hasil uji coba menjadi dasar perbaikan/revisi LKPD untuk menjadi LKPD yang layak untuk digunakan. Kegiatan pada tahap ini adalah validasi para ahli/validator dan hasil uji coba. Dari hasil uji coba diperoleh hasil validasi 85,88\% oleh ahli materi dan 89,33 ahli media. Jadi hasil keseluruhan adalah 87,61\% dengan kategori sangat valid.

Berdasarkan perhitungan di atas terlihat bahwa penggunaan model 4-D (modifikasi 3D) dilakukan melalui proses validasi dan dinyatakan sangat valid baik vaiditas materi maupun media. Setelah melalui proses pengembangan mulai dari perencanaan sampai validasi dan revisi, maka LKPD matematis berbasis PBL terintegrasi nilai nilai Islam maka dihasilkan produk akhir (Draft III).

Setelah selesai mendesain LKPD, kemudian LKPD divalidasi oleh ahli materi dan ahli media. Hasil rata-rata validasi terhadap materi dan desain media LKPD dari kedua tim ahli 
tersebut termasuk dalam katagori sangat valid $(80 \leq \mathrm{P} \leq 100)$ dengan persentase tingkat kevalidan 89,33\% untuk materi, 85,88\% untuk desain media dan tingkat kevalidan secara keseluruhan 89,61\%, yang sebelumnya saran dan komentar dari para ahli dijadikan sebagai masukan bagi peneliti untuk merevisi LKPD. Dengan demikian LKPD matematis berbasis PBL terintegrasi nilai-nilai Islam layak digunakan untuk bahan ajar sebagaimana suswanto dkk (2017: 134) mengemukakan jika kevalidan memiliki persentase diatas 80\% sampai 100\% maka LKPD ini validitasnya berkategori sangat tinggi. Hal ini menunjukkan bahwa LKPD berbasis PBL terintegrasi nilai-nilai Islam yang dihasilkan telah teruji dan sehingga sudah bisa dijadikan sebagai bahan ajar. Hasil riset ini mendukung hasil-hasil riset sejenis, diantaranya Wulandari, E. (2012),pada pembelajaran IPA melalui penerapan PBL ,dan Mauluah, L. (2014) melalui risetnya Pengembangan LKS Matematika Yang Terintegrasi Dengan NilaiNilai Islam Di Kelas IV MI Diponegoro Bantul.

Untuk mengetahui kepraktisan LKPD, maka peneliti menganalisis angket respon siswa yang dibagikan setelah menggunakan LKPD. Dari hasil penelitian diperoleh respon siswa pada kelompok kecil dan terbatas sebagai berikut. Setelah materi dan desain media sudah direvisi dan dinyatakan layak oleh para ahli materi maupun media, selanjutnya peneliti melakukan uji coba produk pada kelompok kecil dan kelompok terbatas. Sebelum uji coba di lakukan, peneliti harus menentukan kelas kontrol dan kelas eksperimen, dimana kelas eksperimen diberikan LKPD matematika berbasis PBL terintegrasi nilai-nilai Islam, sedangkan kelas kontrol yang tidak menggunakan LKPD matematis berbasis PBL terintegrasi nilai-nilai Islam.

Uji coba LKPD ini dilakukan sebanyak 4 kali pertemuan, setiap pertemuan 3 jam pelajaran (3x35 menit). Dalam kegiatan belajar, siswa menggunakan LKPD berbasis PBL terintegrasi nilai-nilai Islam pada materi volume kubus dan balok, yang menuntut siswa untuk aktif dan berdiskusi dengan teman sekelompok untuk menemukan penyelesaian suatu masalah mulai dari menemukan rumus hingga menyelesaikan masalah/soal melalui langkahlangkah PBL, sedangkan guru hanya berperan sebagai fasilitator dan mengarahkan siswa dalam menemukan konsep pembelajaran.

Uji coba kelompok kecil dilakukan pada 6 orang siswa. Hasil respon siswa terhadap penggunaan LKPD matematika berbasis PBL terintegrasi nilai-nilai Islam pada materi volume kubus dan balok yang di peroleh melalui angket praktikalitas kelompok kecil ini termasuk dalam kategori sangat praktis $(80 \leq \mathrm{P} \leq 100)$ dengan persentase tingkat kepraktisan $94,44 \%$ (sangat praktis) (Riduwan, 2011). Sedangkan hasil uji coba kelompok terbatas dapat dilihat pada tabel 1 berikut: 
Tabel 1. Persentase Kepraktisan Uji Coba LKPD Kelompok Terbatas

\begin{tabular}{|c|c|c|c|c|c|}
\hline No & Variabel Praktikalitas LKPD & $\begin{array}{l}\text { Skor yang } \\
\text { Diperoleh }\end{array}$ & $\begin{array}{l}\text { Skor } \\
\text { Maksimal }\end{array}$ & $\begin{array}{l}\text { Nilai } \\
\text { Kepraktisan }\end{array}$ & Kategori \\
\hline 1 & Minat siswa dan tampilan LKPD & 1607 & 1664 & 96,57 & Sangat Praktis \\
\hline 2 & Proses penggunaan & 1574 & 1664 & 94,59 & Sangat Praktis \\
\hline 3 & $\begin{array}{l}\text { Model } P B L \text { terintegrasi nilai nilai } \\
\text { Islam dan kemampuan } \\
\text { Penalaran matematis }\end{array}$ & 1968 & 2080 & 94,62 & Sangat Praktis \\
\hline 4 & Waktu & 342 & 416 & 82,21 & Sangat Praktis \\
\hline 5 & Evaluasi & 395 & 416 & 94,95 & Sangat Praktis \\
\hline \multicolumn{2}{|c|}{ Jumlah } & 5886 & 6240 & 462,945 & \\
\hline \multicolumn{2}{|c|}{ Persentase keidealan (\%) } & 94,33 & & & Sangat Praktis \\
\hline
\end{tabular}

Hasil yang diperoleh dari angket uji coba Kepraktisan kelompok terbatas ini termasuk dalam kategori sangat praktis $(80 \leq \mathrm{P} \leq 100)$ dengan persentase tingkat kepraktisan 94,33\%. Hal ini didukung oleh hasil penilaian siswa dalam menemukan rumus volume kubus dan balok yang didapat oleh siswa.

Berdasarkan hasil respon siswa, baik kelompok kecil atau kelompok terbatas terhadap LKPD matematis berbasis PBL teintegrasi nilai-nilai Islam dengan nilai persentase yang hampir sama yaitu kelompok kecil 94,44\% dan kelompok besar 94,33\% maka LKPD matematis berbasis PBL teintegrasi nilai-nilai Islam ini sangat praktis sehingga layak digunakan hal ini senada dengan apa yang dikemukakan Riduwan (2011: 11) bahan ajar akan bernilai sangat praktis jika memiliki persentase kepraktisan $80 \leq \mathrm{P} \leq 100$.

Sedangkan untuk melihat keefektifan LKPD, maka peneliti menggunakan uji t melalui hasil postest kemampuan penalaran siswa.Ternyata $t_{\text {hitung }}>t_{\text {tabel }}$ yaitu 6,136 $>2,021$ pada tingkat siginifikan 5\% Artinya terdapat perbedaan kemampuan antara kelas V Al-Halim sebagai kelas eksperimen yang menerapkan pembelajaran menggunakan LKPD berbasis PBL teintegrasi nilai-nilai Islam dengan kelas V Al-fattah sebagai kelas kontrol yang menerapkan pembelajaran konvensional.

Selain hasil dari uji t yang menunjukan keefektifan dari LKPD Matematis berbasis PBL terintegrasi nilai-nilai Islam, LKPD ini juga dinilai efektif karena memberikan dampak 
positif terhadap hasil belajar dimana hasil belajar siswa setelah menggunakan dengan LKPD Matematis berbasis PBL terintegrasi nilai-nilai Islam memiliki ketuntasan hasil belajar 85\% pada materi volume kubus dan balok dalam rangka memfasilitasi kemampuan penalaran siswa dengan KKM 75. Hal ini sesuai dengan apa yang dikemukakan Nieeven dalam sannah dkk (2015: 184-196) Aspek keefektifan dipenuhi apabila hasil dari penggunaan produk menghasilkan pencapaian yang diharapkan. Senada juga dengan apa yang dikemukan oleh prasetyo dalam Sannah dkk (2015: 184-196) keefektifan diukur berdasarkan ketuntasan belajar siswa secara klasikal dengan syarat siswa yang tuntas jumlahnya lebih besar atau sama dengan 85\%. Penelitian yang sejenis juga ditunjukan penelitian Utami (2017) dengan judul Penelitian "Pengembangan Perangkat Pembelajaran Matematika Berbasis PBL Bernuansa Islam Untuk Mengukur Kemampuan Berfikir Kritis Siswa Pada Pokok Bahasan Barisan Dan Deret". Hasil penelitian menunjukan bahwa perangkat pembelajaran dinilai sangat efektif dilihat dari tingkat penguasaan siswa, penilaian aktifitas siswa dan respon siswa melalui angket serta ketuntasan hasil belajar tercapai karena lebih dari $90 \%$ di atas KKM. Selain itu juga mendukung riset Mulyana (2015) khususnya pada peningkatan kemampuan penalaran matematik dan kemandirian belajar Siswa SMP Melalui Pembelajaran Berbasis Masalah.

\section{SIMPULAN DAN SARAN}

Berdasarkan hasil pengembangan yang telah diuraian, dapat lah disimpulkan bahwa:1) LKPD matematika berbasis PBL terintegrasi nilai-nilai Islam pada pokok bahasan volume kubus dan balok dinilai sangat valid, praktis dan efektif, sehingga sangat layak digunakan sebagai bahan ajar dalam pembelajaran khusus Sekolah Islam; 2) Tingkat keefektifan dapat diukur dari tingkat ketuntasan kemampuan penalaran siswa hasil belajar lebih besar atau sama dengan $85 \%$.

Dalam penelitian ini disarankan agar LKPD Matematis Berbasis PBL Terintegrasi Nilai-nilai Islamini digunakan dalam pembelajaran kubus dan balok karena telah diuji cobakan dengan hasil yang baik, untuk peneliti selanjutnya dapat mengembangkan LKPD Matematis Berbasis PBL Terintegrasi Nilai-nilai Islam pada materi yang berbeda atau mengkolaborasikan dengan metode lain. Selain itu kepada peneliti lain yang akan melakukan penelitian mengenai pengembangan LKPD Matematis Berbasis PBL Terintegrasi Nilai-nilai Islam pada materi Voluume Kubus dan Balok disarankan untuk memperhatikan efisiensi waktu agar dapat berjalan secara maksimal. 


\section{DAFTAR PUSTAKA}

Aviyanti, Z. (2015). Validitas LKS Berorientasi 5M Materi Perubahan Lingkungan dan Daur Ulang Limbah untuk Melatihkan Siswa Memecahkan Masalah. BioEdu, 4(1).

Buchory, M. S., Rejeki, S., \& Purwanti, R. S. (2014). Pengembangan Model Pembelajaran Tematik Kelas Awal Sekolah Dasar. Sekolah Dasar: Kajian Teori dan Praktik Pendidikan, 22(1).

Hariyani, Mimi .(2013). Strategi Pembelajaran Matematika Madrasah Ibtidaiyah Berintegrasi Nilai-nilai Islam.Menara, (12)(2), h.152.

Hendriana, Heris. (2018). Hard Skill dan Soft Kill Matematika Siswa. (Cimahi: Refika Aditama) Lintang, A. C., Masrukan, M., \& Wardani, S. (2017). PBL dengan APM untuk Meningkatkan Kemampuan Pemecahan Masalah dan Sikap Percaya Diri. Journal of Primary Education, 6(1), 27-34.

Mauluah, L. (2014). Pengembangan LKS Matematika Yang Terintegrasi Dengan Nilai-Nilai Islam Di Kelas IV MI Diponegoro Bantul. Jurnal Al Bidayah, 6(1).

Mikrayanti.(2016). Meningkatkan Kemampuan Penalaran Matematis melalui Pembelajaran berbasis Masalah. Suska Journal of Mathematics Education, (2)(2), 97 -102.

Mulyana, Ade. (2015). Meningkatkan Kemampuan Penalaran Matematik Dan Kemandirian Belajar Siswa SMP Melalui Pembelajaran Berbasis Masalah. Dikdaktik, (9)(1),40-51

Norsanty, U. O., dan Chairani, Zahra. (2016). Pengembangan Lembar Kerja Siswa (Lks) Materi Lingkaran Berbasis Pembelajaran Guided DiscoveryUntuk Siswa SMP Kelas VIII. Math Didactic: Jurnal Pendidikan Matematika, (2)(1), 13-23.

Nur, S., Pujiastuti, I. P., \& Rahman, S. R. (2016). Efektivitas Model Problem Based Learning (Pbl) terhadap Hasil Belajar Mahasiswa Prodi Pendidikan Biologi Universitas Sulawesi Barat. Saintifik: Jurnal Matematika, Sains, dan Pembelajarannya, 2(2), 133-141.

Riduwan. (2011). Belajar Mudah Penelitian untuk Guru-Karyawan dan Peneliti Pemula, Bandung: Alfabeta.

Suswanto,dkk. (2011). Penelitian Pendidikan. Medan: Tira Smart. 2017. h.134, dan Furchan. “Pengantar pendidikan”.Pengantar penelitian Pendidikan”.Malang: Pustaka Belajar. h.181

Partasiwi, N., Hasyim, A., \& Sutiarso, S. (2017). Pengembangan Lembar Kerja Siswa Trigonometri Dengan Model Problem Based Learning. Jurnal Teknologi Informasi Komunikasi Pendidikan (Old), 5(1). 
Rofiah, N. H. (2014). Pengembangan Lembar Kerja Peserta Didik (LKPD) Berbasis Kit untuk Meningkatkan Keterampilan Proses Dasar IPA di MI/SD. Jurnal Al Bidayah, 6(2).

Sannah, dkk, Pengembangan Lks Dengan Model Discovery Learning Pada Materi Teori Atom Bohr, Jurnal Pendidikan dan Pembelajaran Kimia, Vol. 4, No.1 Edisi April 2015, 184-196

Salafudin. (2015). Pembelajaran Bermuatan Nilai-Nilai Islam. Jurnal Penelitian,(12)(2), 223243.

Setiawan, T. , Sugianto, dan Junaedi, I. (2012). Pengembangan Perangkat Pembelajaran Matematika Dengan Pendekatan Problem Based Learning Untuk Meningkatkan Keterampilan Higher Order Thinking. Unnes Journal Of Research Mathematics Education, (1)(1),

Syahrir, S., \& Susilawati, S. (2015). Pengembangan Modul Pembelajaran Matematika Siswa SMP. Jurnal Ilmiah Mandala Education (JIME), 1(2), 162-171.

Wulandari, E. (2012). Penerapan Model PBL (Problem Based Learning) Pada Pembelajaran IPA Siswa Kelas V SD. Kalam Cendekia PGSD Kebumen, 1(1).

Utami, Y. T. (2017). Pengembangan Perangkat Pembelajaran Matematika Berbasis Problem Based Learning Bernuansa Islami Untuk Mengukur Kemampuan Berpikir Kritis Siswa pada Pokok Bahasan Barisan dan Deret (Doctoral dissertation).

MZ, Z. A. (2013). Intergrasi Pendidikan Nilai Islam dalam Pembelajaran Matematika di Sekolah Menengah Pertama/Madrasah Tsanawiyah Sebagai Upaya Pembinaan Akhlak Siswa (Studi Kasus di SMP IT Al-Fiityah dan MTsN Pekanbaru). 